https://doi.org/10.15407/scine16.03.050

\author{
SENKIN, V.S., and SYUTKINA-DORONINA, S.V. \\ Institute of Technical Mechanics, the NAS of Ukraine \\ and the State Space Agency of Ukraine, \\ 15, Leshko-Popel St., Dnipro, 49005, Ukraine, \\ +380 $563720640,+38056372$ 0640, office.itm@nas.gov.ua
}

\title{
CHOICE OF THE PARAMETER OPTIMIZATION METHOD FOR A GUIDED MISSILE
}

Introduction. The design of guided missiles is connected with high costs of material and financial resources. The need to reduce them at the initial design phase of guided missiles imposes stringent requirements to formalization of design problems, the solution methods, the adequacy of mathematical models employed and the quality of design solutions.

Problem Statement. One of the design problems for guided missiles is to develop methodology for optimization of design parameters and motion control programs of guided missiles.

Purpose. The aim of the article is to develop methodology to optimization of design parameters and control programs, as well as the formalization of problem and the choice of method to optimize the characteristics of guided missiles capable of flying along different trajectories.

Materials and Methods. Deterministic optimization methods are used to solve the problem of nonlinear mathematical programming with limitations in form of equality, inequality and differential constraints.

Results. The application programs have been developed to solve the optimization problem for single-stage guided missile with solid rocket motors. The developed methodology has been tested by solving design problem of hypothetical guided missile with a starting weight of $300 \mathrm{~kg}$ that is capable of flying along a ballistic trajectory for vertical and oblique types of start. The use of the Hooke-Jeeves zero-order pattern search, which does not use the calculation of partial derivatives of the objective function by optimization parameters, which most reduces the search time of the optimal solution of the complex problem, was shown to be expedient.

Conclusion. The developed methodology allows one to determine, to the accuracy required in design studies, the flight control programs optimal in a given class of functions and advisable values of the design parameters and basic characteristics for guided missiles.

Keywords: guided missile, mathematical model, design parameters, trajectory parameters, motion control programs, optimization, initial design phase, and solid rocket motors.

One of the priority directions of rocket and space technology development is the creation of technologies for designing new rocket engines on environment friendly propellant components; new satellites, satellite communication systems, Earth remote sensing systems;

Citation: Senkin, V.S., and Syutkina-Doronina, S.V. Choice of the Parameter Optimization Method for a Guided Missile. Sci. innov. 2020. V. 16, no. 3. P. 50-64. https://doi.org/10.15407/scine16.03.050 
and new guided missiles (GM) to ensure the interests in the field of national security and defense [1].

The design of GM for various purposes is associated with significant costs of material and financial resources [2-5]. The need to take into account these factors at the initial stage of $\mathrm{CO}$ design implies increased requirements for the formalization of design problems, methods for their solution, the adequacy of mathematical models used, and the quality of design solutions. It should be noted that incorrect (irrational) decisions made at the initial stage of design lead to a decrease in the efficiency of the fulfillment of missions by GM and an increase in the costs and time for its creation $[6,7]$. The search for optimal ways to solve the above mentioned problems justifies the relevance of this research.

In these conditions, the development of methodological framework is of particular importance, since at the initial stage of design, it makes it possible, with the necessary accuracy for design, to quantitatively assess the objective functional that defines the GM design quality, optimal (rational) values of optimized parameters, aerodynamic and GM ballistic characteristics, and traffic control programs in different sections of the trajectory.

Out of many possible options, the optimal (rational) design of the GM shall be considered the project that provides the highest value of the objective functional (one of the most important indicators of the $\mathrm{CO}$ efficiency), while other performance indicators shall either reach the specified values or vary in the required range.

The complex problem of optimizing the design parameters, the trajectory parameters, and GM motion control programs is formulated below; an approach to the formation of motion control programs at the initial stage of designing GM that flies on different ballistic trajectories has been proposed.

A one-stage spacecraft with a solid rocket propellant (SRP) engine, which delivers a required mass of reentry vehicle to a given point in space is considered a guided missile.
The complex problem of optimizing the design parameters, the trajectory parameters, and GM control programs belongs to the class of problems of the theory of optimal control with constraints in the form of equalities, inequalities, and differential relations [8-15]. The problem is formalized by selecting the optimization criteria (objective functional) and by developing a mathematical model that allows determining the objective functional values, depending on the available initial data (vector $\bar{x}$ ), the parameters to be optimized, which include the GM basic design parameters, trajectory parameters (vector $\bar{p}$ ), and control programs (vector $\vec{u}$ ) To solve the complex problem, it is also necessary to develop an effective optimization method that enables quick automatic determination of parameters to be optimized $\left(\bar{p}_{\text {opt }}\right)$, and CO motion control programs $\bar{u}=$ $=\bar{u}_{\text {opt }}(t)$, at which the objective functional has an optimal value.

The range $L=L(\bar{x}, \bar{p}, \bar{u})$ to which the required mass of reentry vehicle $m_{\Gamma ч}$ shall be delivered, at a given initial (launch) mass of the GM $m_{0}$. is further considered the objective functional. The optimal values of the parameters and the GM motion control programs are determined based on the condition of the maximum value of objective functional.

The initial information (vector $\bar{x}$ components) necessary for solving the complex problem includes: data of terms of reference that determines the target; conditions for GM launch; restrictions on the flight trajectory, dimensional and mass characteristics of the GM as a whole, its individual subsystems and elements; physical and mechanical properties of the used construction materials; properties of solid rocket propellant; unaccounted masses of elements and subsystems not included in the mathematical model for calculating the GM basic characteristics.

The optimized parameters (vector $\bar{p}$ components) are the main design parameters that, at the initial stage of design, allow determining the overall mass and energy of the GM as a whole and of the solid rocket propellant engine as part 
of it and the parameters that, together with optimized motion control programs, define the trajectory of the GM and the value of the objective functional.

The composition of the main GM design parameters includes the initial thrust coefficient $v_{\mathrm{p}}$ and the relative remaining mass $\mu_{\mathrm{v}}$, which are defined by the generally accepted relations [2-5]:

$$
\begin{gathered}
v_{\mathrm{p}}=\frac{m_{0} \cdot g_{0}}{P_{p u s t}} ; \\
\mu_{\mathrm{k}}=\frac{m_{0}-m_{m}}{m_{0}}=\frac{m_{\mathrm{k}}}{m_{0}},
\end{gathered}
$$

where $m_{k}$ is remaining mass of the $\mathrm{GM} ; g_{0}-$ is acceleration of gravity on the Earth surface; $m_{m}$ is total propellant margin; $P_{\text {pust }}$ is SRP sustainer thrust in space, in the main mode.

The SRP engine design parameters included in to the vector of parameters to be optimized $\bar{p}$ comprise pressure in the combustion chamber, in the main operation mode $p_{k}$, diameter of nozzle section $D_{a}$, full operation time of SRP sustainer $t_{\Sigma}$ that depends on initial thrust coefficient $v_{p}$.

The GM motion is controlled in accordance with pitch programs on the $j$-th sections of the trajectory, which are optimized

$$
\varphi_{j}=\varphi_{n p j}(t), j=\overline{1, N_{\mathrm{yu}}},
$$

where $N_{\mathrm{yu}}$ is the number of sections in the GM trajectory for a given mission profile [11-17].

The set of parameters that determine the ballistic trajectory and are included in the vector of parameters to be optimized $\bar{p}$ depends on the selected mission profile and may include the following parameters:

- duration of the vertical section $t_{\text {vert }}$ in the case of vertical launch;

- initial angle of GM tilt in the case of oblique launch $\varphi_{\mathrm{cm}}$;

- pitch angle at the end of the active section of the trajectory $\varphi_{A U T}$;

- duration of entering the zero angle of attack $t_{P U T 1}$ after the end of the active leg/powered trajectory;
- constant angle of attack $\alpha_{\text {const }}$ on an inactive leg/unpowered portion of the trajectory, when using an option of the ballistic trajectory;

- duration of entering the angle of attack $\alpha=$ $\alpha_{\text {const }}$ after reaching the maximum altitude $t_{\text {PUT3. }}$.

While forming a specific trajectory, it is possible to meet a set of requirements and restrictions on the motion parameters and GM characteristics, in particular, the limitations on maximum altitude $H_{\max }=H_{\max }^{m p}$, minimum air velocity pressure at the maximum altitude $Q_{H_{\max }} \geq Q_{H_{\max }}^{\min }$, and on maximum attack angle in all portions of the trajectory $\alpha \leq \alpha_{\max }$; the requirements for mass of reentry vehicle $m_{\Gamma ч}=m_{\mathrm{\Gamma \Psi}}^{m}$, total length of the GM $L_{\mathrm{yPO}}=L_{\mathrm{yPO}}^{m p}$, launch mass of the GM $m_{0}=m_{0}^{m p}$, and maximum permissible diameter of the GM $D_{\mathrm{ypO}}=D_{\mathrm{ypO}}^{m p}$.

It should be noted that a certain complex of above mentioned conditions, limitations, and requirements corresponds to each specific design problem.

Design parameter $\mu_{k}$ Bin (1) is determined at given mass of reentry vehicle $m_{\mathrm{\Gamma u}}^{m p}$ and launch mass of the GM $m_{0}$ from the condition of placement of maximum amount of solid rocket propellant in the considered option of GM.

As mentioned above, the following parameters are considered components of GM motion control program vector $\bar{u}=\bar{u}(t)$ pitch programs $\varphi_{n p}(t)$ Hon active (powered) and inactive (unpowered) legs, with motion control programs on the mentioned portions described by polynomials [11-17]:

$$
\varphi_{n p j}(\bar{p}, \bar{y}, t)=\sum_{i=0}^{N} A_{j i}(\bar{p}, \bar{y}) \cdot t^{i},
$$

where coefficients $A_{i j}$ are determined depending on the $j$-th portion of the trajectory, the vector of parameters to be optimized $\bar{p}$, and current values of phase coordinate vector $\bar{y}$ that defines the GM position in space.

This approach to the selection of motion control programs has enabled reducing the problem of the optimal control theory [8-10] to a simpler program of nonlinear mathematical programming with limitations in the form of equalities 


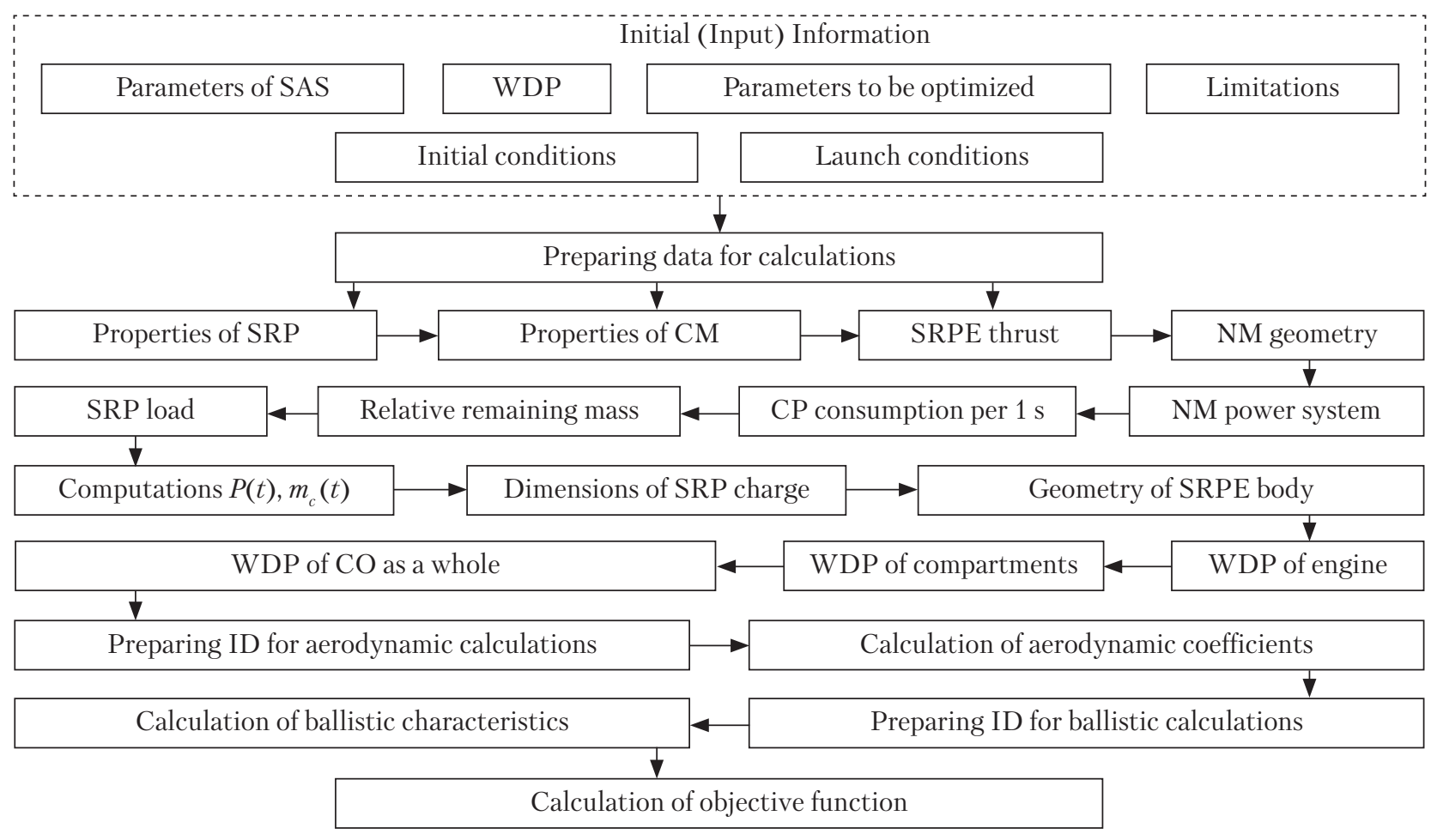

Fig. 1. Structure of GM mathematical model: SAS - structural assembly scheme; WDP - weight and dimension properties; SRP - solid rocket propellant; CM - construction materials; SRPE - solid rocket propellant engine; NM - nozzle module; $\mathrm{CP}$ - combustion products; ID - input data; $P(t)$ - time dependence of SRPE thrust; $m_{c}(t)$ - time dependence of combustion product consumption per $1 \mathrm{~s}$

and differential relations [11-17], where the objective functional is represented by an objective function that depends only on the vector of optimized parameters $\bar{p}$. In this case, the complex problem of optimization of design parameters and control programs (3) is formulated as follows. It is necessary to determine the value of optimized parameters vector $\bar{p}=\bar{p}_{\text {opt }}$, which ensures the maximum objective function

$$
I\left(\bar{p}_{\text {opt }}, \bar{x}\right)=\max _{p} L(\bar{p}, \bar{x}),
$$

Under the limitations:

on the range of parameters to be optimized $\bar{p}$ and initial data $\bar{x}$ :

$$
\bar{p} \in \tilde{P}^{m} \subset P^{m}, \bar{x} \in \tilde{X}^{k} \subset X^{k} ;
$$

on the trajectory parameters:

$$
\begin{gathered}
H_{\max }=H_{\max }^{m p}, Q_{H_{\max }} \geq Q_{H_{\max }}^{\min }, \alpha \leq \alpha_{\max }, \\
\frac{d y}{d t}=f(\bar{y}, \bar{x}, \bar{p}), \bar{y} \in \tilde{Y}^{S} \subset Y^{s} ;
\end{gathered}
$$

on GM weight and dimensions:

$$
\begin{gathered}
m_{0}(\bar{x}, \bar{p})=m_{0}^{m p}, m_{\Gamma \mathrm{Y}}(\bar{x}, \bar{p})=m_{\Gamma \mathrm{\Gamma Ч}}^{m p}, \\
L_{\mathrm{yPO}}=L_{\mathrm{y}}^{m p}, L_{\text {ГЧ }}=L_{\text {ГЧ }}^{m p}, D_{\mathrm{yPO}}(\bar{x}, \bar{p})=D_{\mathrm{yPO}}^{m p} .
\end{gathered}
$$

In relationships $(4)-(8)$ the following notations are used:

$\bar{x}=\left(x_{i}\right), i=\overline{1, k}$ is the initial data vector that is an element of real vector space $X^{k} ; \bar{p}=\left(p_{i}\right), i=\overline{1, m}$ is the vector of parameters to be optimized, which is an element of real vector space $P^{m} ; \widetilde{P}^{m} ; \tilde{X}^{k}$ are closed domains in the real vector spaces $P^{m}, X^{k}$, where vectors $\bar{p}, \bar{x}$, may take on values, respectively; $\bar{y}=\left(y_{i}\right), i=\overline{1, s}$ is the phase coordinate vector that defines the GM position in space, is an element of real vector space $Y^{s} ; \tilde{Y}^{\mathrm{s}}$ is closed domain in the vector space $Y^{s}$, where vector $\bar{y}$ may take on values; $\alpha, \alpha_{\max }$ are design and maximum permissible attack angles on all portions of the trajectory; $m_{0}=(\bar{x}, \bar{p}), m_{0}^{m p}$ are design and re- 
quired launch masses of the $\mathrm{GM} ; m_{\mathrm{\Gamma \Psi}}=(\bar{x}, \bar{p}), m_{\mathrm{\Gamma \Psi}}^{m p}$ are design and required masses of the reentry vehicle; $L_{\mathrm{ypO}}, L_{\mathrm{yPO}}^{m p}$ are design and required lengths of the GM; $L_{\Gamma \Psi}, L_{\Gamma \Psi}^{m p}$ are design and required lengths of the reentry vehicle; $D_{\text {уро }}(\bar{x}, \bar{p}), D_{\mathrm{yPO}}^{m p}$ are design and required diameters of the GM.

The GM mathematical model is represented as operator $\tilde{F}=R(z)$ with the domain on the set $Z=\tilde{X}^{k} \times \tilde{P}^{m}$ and the range on the set $F$ that match each element from the set $z(\bar{x}, \bar{p}) \in Z$ to the set of GM initial data $\tilde{F} \subset F$.

The initial data obtained from solving the complex problem are the value of objective function $L$ (GM range), optimal value of the vector of parameters to be optimized $\bar{p}_{\text {opt }}$ GM motion control programs $\varphi_{n p j}\left(\bar{p}_{o p t}, \bar{y}, t\right)$ in different portions of the trajectory, weight and dimensions of the GM as a whole and of its individual basic elements and subsystems; strength, aerodynamic, ballistic, and power parameters of the GM.

The formulated complex problem of optimization of design parameters and control programs depending on the chosen set of limitations (5)(8) can be used in the design of controlled objects of different classes, which fly on given options of the ballistic trajectory.

The system of motion equations of the GM center of mass used in solving the formulated complex problem, in the projections on the axis of the terrestrial coordinate system has been given in [18]. Mathematical models for determining the main characteristics of the GM as a whole and its subsystems and elements have been considered in detail in $[2-5,11-17,19-22]$.

The structure of the mathematical model, the sequence of calculation of the objective function (4) for the optimization of the vector of parameters and the main characteristics of the GM is shown in Fig. 1.

\section{CONTROL PROGRAM FORMATION}

GM ballistic trajectory can be realized both with vertical and oblique launches.

One of the options of GM ballistic trajectory with a vertical launch consists of four portions [14, 17]:
- vertical portion with duration $t_{\text {vert }}$, where the pitch program is constant, i.e. not time variant: $\varphi_{n p}^{\text {vert }}=90^{\circ}$;

- active leg (powered portion), where the pitch program (3) that ensures a U-turn of GM in the vertical plane is chosen based on a given pitch angle $\varphi=\varphi_{A U T}$ at the end of this portion of trajectory;

- the first inactive leg (unpowered portion), where the pitch program (3) at the end of this portion ensures entering the attack angle $\alpha_{1}=$ $=0,0^{\circ}$ within a given time $t=t_{\text {PUT1 }}$;

- the second inactive leg, where the pitch program (3) can be chosen based on the trajectory limitations (6);

- the third inactive leg, where GM flies with a zero attack angle $\alpha=0.0^{\circ}$ until collides with the Earth's surface.

In the case of oblique (towards aim point) launch, there is no vertical portion, and the pitch program (3) ensures a U-turn in the vertical plane starting with the launch moment. Further, the GM moves according to the same mission profile as in the case of vertical launch [17].

The second option of ballistic trajectory differs from the first one only by motion with a nonzero attack angle $\alpha=\alpha_{\text {const }}$ after reaching the maximum altitude.

Let us consider the following parameters to be optimized, which describe the ballistic trajectory: duration of vertical portion in the case of vertical launch $t_{\text {vert }}$, pitch angle $\varphi_{A U T}$ at the end of the active leg, duration of the first inactive leg with entering a zero attack angle $t_{P U T 1}$ pitch angle $\varphi_{c m}$ in the case of oblique (towards aim point) launch, attack angle $\alpha_{\text {const }}$ on the last inactive leg, duration of entering attack angle $\alpha=\alpha_{\text {const }}$ after reaching the maximum altitude $t_{\text {PUT3 }}$.

The relationships for determination of coefficients $A_{i j}$ in (3) have been considered in details in $[15,17]$.

\section{CHOSING AN OPTIMIZATION METHOD}

Based on the analysis of deterministic numerical optimization methods that can be used to solve the 
formulated complex problem, a group of methods that automatically find the extremum of the objective function has been selected. The applicability of these methods for operative choice of design parameters and parameters of different GM trajectories has been assessed.

Numerical optimization methods belong to the iterative class [23], i.e. they generate a sequence of vectors of parameters to be optimized, in accordance with the proposed set of rules, including the criterion of completion of the search for the extremum of the objective function. With a given initial vector of optimized parameters $\bar{p}_{0}$ the optimization methods generate a sequence of vectors $\bar{p}_{0}, \bar{p}_{1}, \bar{p}_{2}, \ldots$. Transformation of the vector of optimized parameters $\bar{p}_{j}$ into $\bar{p}_{j+1}$ is an iteration, where $j=\overline{0, M}, M$ is the limit number of iterations in optimizing computations.

While analyzing the optimization methods, the problem of finding the maximum of multi-extremum function has been considered

$$
f\left(\bar{p}_{\text {opt }}\right)=\max _{\bar{p} \in R^{n}} f(\bar{p}) .
$$

The solution of problem (9) is associated with forming a sequence of vectors of optimized parameters $\left\{\bar{p}_{j}\right\}, j=\overline{0, M}$, which, for finding the maximum of the objective function, have the following property:

$$
f\left(\bar{p}_{j+1}\right)>f\left(\bar{p}_{j}\right), j=\overline{0, M} .
$$

The general rule for building a sequence of vectors of optimized parameters $\left\{\bar{p}_{j}\right\}$ is as follows:

$$
\bar{p}_{j+1}=\bar{p}_{j}+\bar{t}_{j} \cdot \overline{d^{j}}, j=\overline{0, M},
$$

where $\bar{p}_{0}$ is the initial vector of optimized parameters; $\bar{t}_{j}$ is the set of steps for all parameters to be optimized. These steps are required for transforming vector $\bar{p}_{j}$ into vector $\bar{p}_{j+1}$ while meeting condition (10); $\dot{d}^{j}$ is the set of search directions, which alternates by all parameters to be optimized.

The initial value of the vector of optimized parameters $\bar{p}_{0}$ is given based on a given range of its variation and the availability of a priori information on the position of points of extremums of the objective function. Steps from the set $\overline{t_{j}}$ are grea- ter than zero and selected based on either (10), or the condition for the maximum of the objective function along a given search direction

$$
f\left(\bar{p}_{j}+\bar{t}_{j} \cdot \overline{d^{j}}\right) \rightarrow \max _{\bar{t}_{j}}
$$

In this case, selecting steps $\bar{t}_{j}$ based on condition (12) enables the optimization of parameters in all directions $\overline{d^{j}}$ in the fastest way.

Sequence $\left\{\bar{p}_{j}\right\}$ is maximizable, provided $\lim _{j \rightarrow \infty} f\left(\bar{p}_{j}\right)=f\left(\bar{p}_{\text {opt }}\right)$ and the sequence converges to the maximum of the objective function

$$
f\left(\bar{p}_{\text {opt }}\right)=\max _{\bar{p} \in R^{n}} f\left(\bar{p}_{j}\right) .
$$

The analysis of the developed deterministic optimization methods [23] has made it possible to separate a group of methods that, from our point of view, are advisable to be used at the initial stage of GM design for automatic solution of the formulated complex problem of optimization. This group includes: the gradient-type methods of the first and second orders coordinate descent with alternating changes of the optimized parameters, the zero-order flexible polyhedron method (the Nelder-Mead method), and the zero-order configurations method (the Hooke-Jeeves method).

It should be noted that solving the complex problem using the gradient-type methods of coordinate descent requires calculating the gradient of the objective function by numerical differentiation, at each iteration, which significantly increases the number of calculations of the objective function and, consequently, the time to find the optimal solution. In addition, with small steps of varying each design parameter, the gradient method is not always able to find the global maximum, because the sequence of points formed by the method may coincide with the point of local extremum. If the steps of varying each optimized parameter are too large, the global optimum may be "skipped". The results of the gradient-type method of first and second order coordinate descent and its algorithm have been considered in [24,25].

The deterministic zero-order flexible polyhedron method (the Nelder-Mead method) does not 


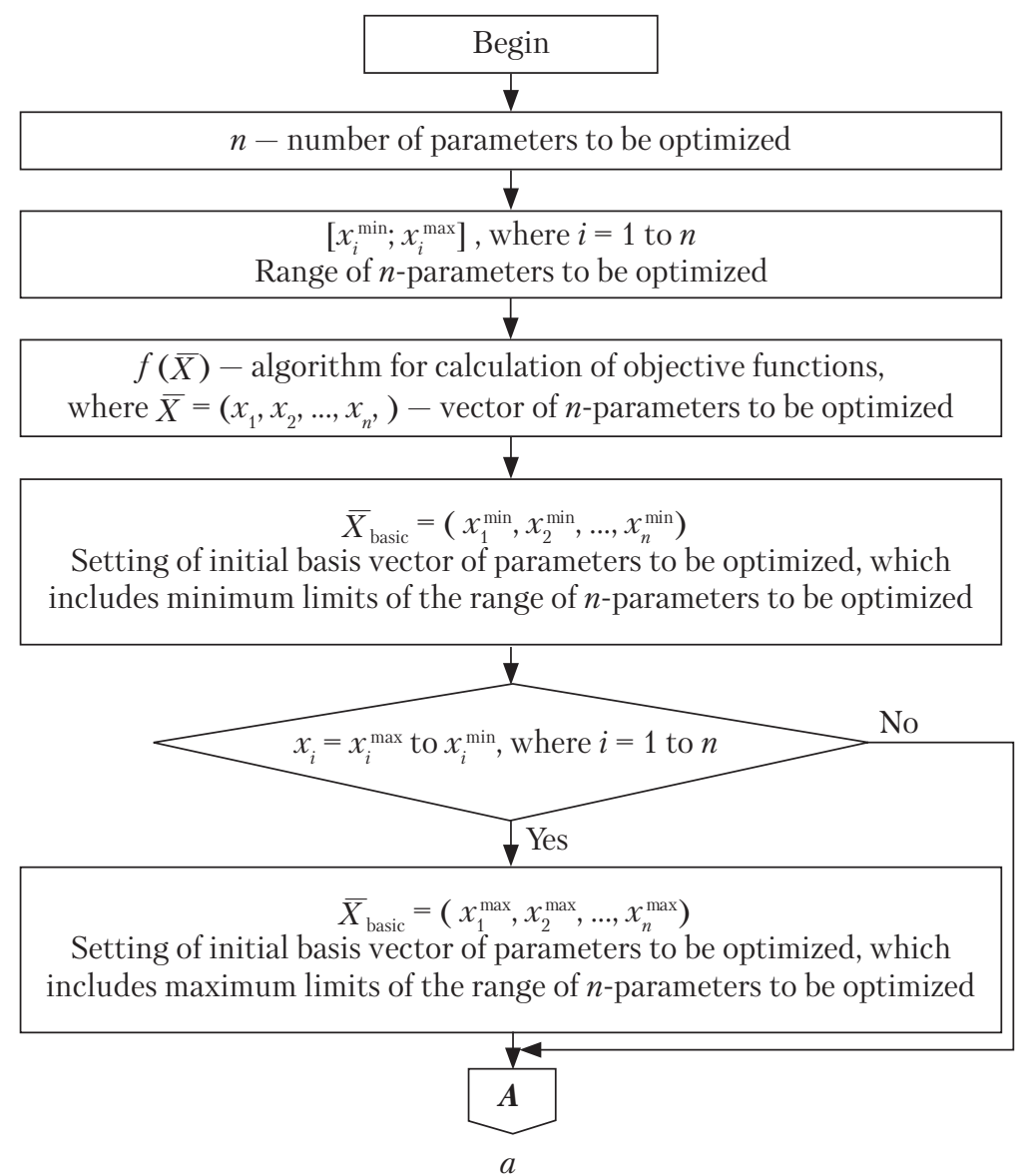

Fig. 2. Block diagram of the algorithm for the Hooke-Jeeves configuration method: $a$ - the first part of the block diagram, where the ranges of parameters, the initial basis vector of optimized parameters, and the algorithm for calculating the objective function are set; $b$ - the second part of the block diagram, which sets the necessary method constants and initial steps for the parameters to be optimized; $c$ - the third part of the block diagram where the exploratory search on each parameter to be optimized is realized; $d$ - the fourth part, where the analogical search for each parameter to be optimized is realized; at the end of the block diagram the vector of optimized parameters that ensures the maximum value of the objective function is determined (Look the same p. 56-59)

require the calculation of partial derivatives of the objective function for each optimized parameter. This significantly decreases the number of calculations of the objective function and, consequently, reduces the search time. However, the flexible polyhedron method is not always able to find the global maximum of the objective function, as it may close the vertices of the convex polyhedron with a local optimum in the center of mass of the polyhedron. The results of the zeroorder flexible polyhedron method and its algorithm have been described in [25].
Like the Nelder-Mead method, the deterministic method of zero-order configurations (HookeJeeves method) [25] does not require the calculation of partial derivatives of the objective function for each optimized parameter. Using the Hooke-Jeeves method it is possible to set small steps of variation of each optimized parameter and not too small advance factor for analogical search, which gives a chance, due to an increase in the number of search stages, to avoid "skipping" the global optimum and forming a sequence of points that converge in the point of local optimum. The 


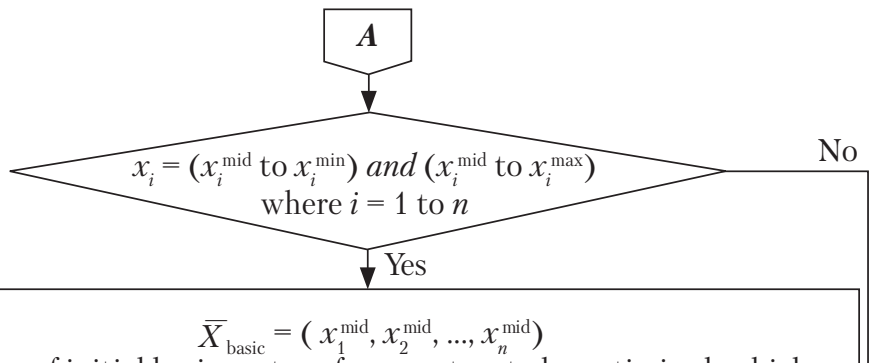

Setting of initial basis vector of parameters to be optimized, which includes average values of the range of $n$-parameters to be optimized

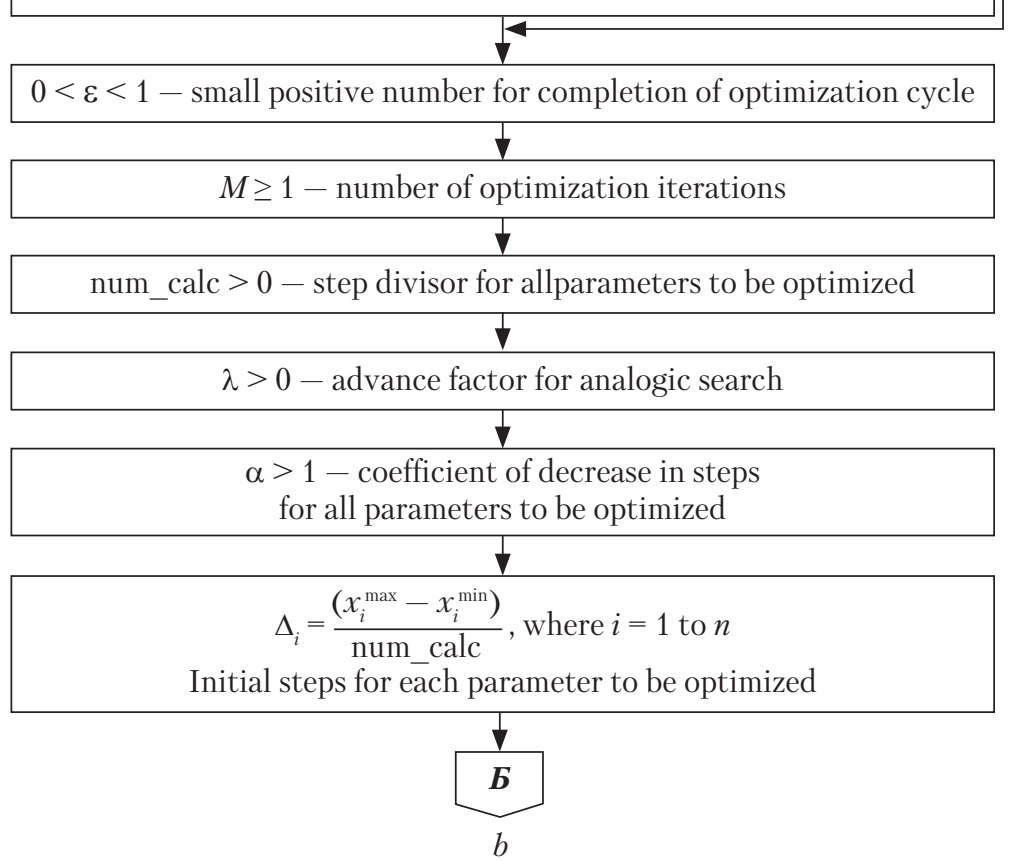

Fig. 2. Continuation

method of zero-order configurations is a combination of the exploratory search, when the optimized parameters alternate each other, in different directions, and the advanced analogical search [23]. The research is focused on identifying the local behavior of the objective function and determining the direction of growth of the objective function along the "ravines". The information obtained is used further for analogical search while moving along the "ravines".

The exploratory search begins with a given initial vector of optimized parameters, which is called the old basis. Further, the values of the steps are formed, they are different for each parameter that is optimized (component of vector $\bar{p}$ ) and variable in the search process. Alternately, one of the optimized parameters is selected, and a step towards its increase is taken. If the value of the objective function at the obtained test point is greater than that at the starting point, the step is considered successful. Next, the variable parameter is returned to the previous point and a step in the opposite direction is taken, followed by analyzing the behavior of the objective function. If the value of the objective function at one of the obtained test points is greater than the that at the starting point of this optimized parameter, then the step is considered successful. Having searched all the optimized parameters alternately, the search is completed. The obtained vector of optimized 


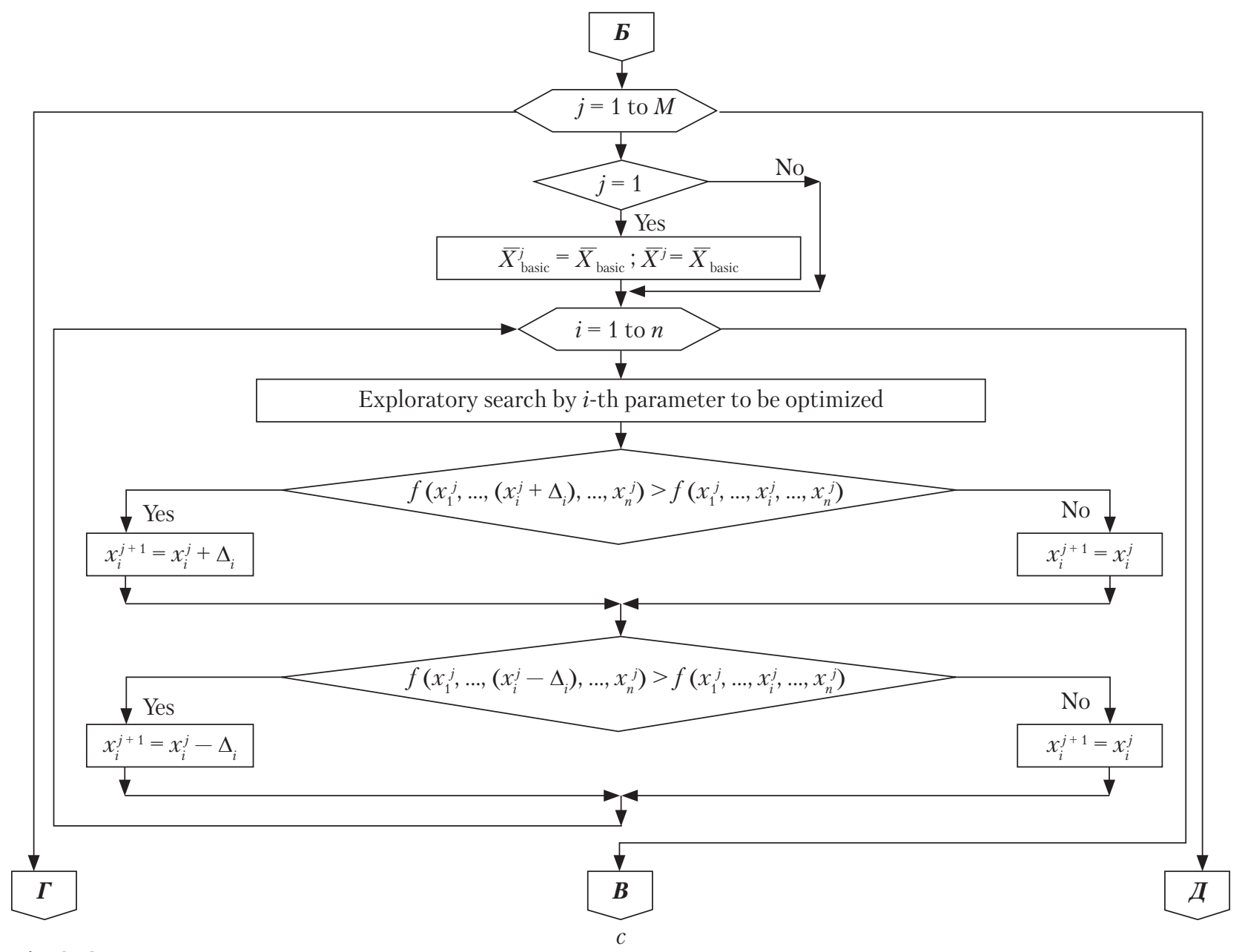

Fig. 2. Continuation

parameters $\bar{p}$ is called the new basis. The exploratory search is followed by an analogical search that is moving from the old to the new basis, with the accelerating factor $\lambda>0$ set. Success of analogical search of new vector of parameters to be optimized is defined with the help of exploratory search of new vector of optimized parameters $\bar{p}$. If the value of objective function in the best point of new value of vector $\bar{p}$ obtained from the exploratory search is greater than that in the point of previous (old) basis, the analogic search is successful.

If the analogic search is unsuccessful, the vector of optimized parameters is returned to the old basis, where the exploratory search continues with reduced steps for each optimized parameter. The search for the optimal solution is completed when all the current values of the steps for each optimized parameter become less than a given small value $0<\varepsilon<1$.

As the results of research $[24,25]$ have shown, for the same time of operation of the considered optimization algorithms in automatic mode, the highest value of the objective function is obtained using the zero-order configurations method (the Hooke-Jeeves method), which makes it appropriate for quickly solving the complex problem of optimization of GM parameters.

Fig. 2 shows a block diagram of the configuration (Hook-Jeeves) method algorithm used in an 


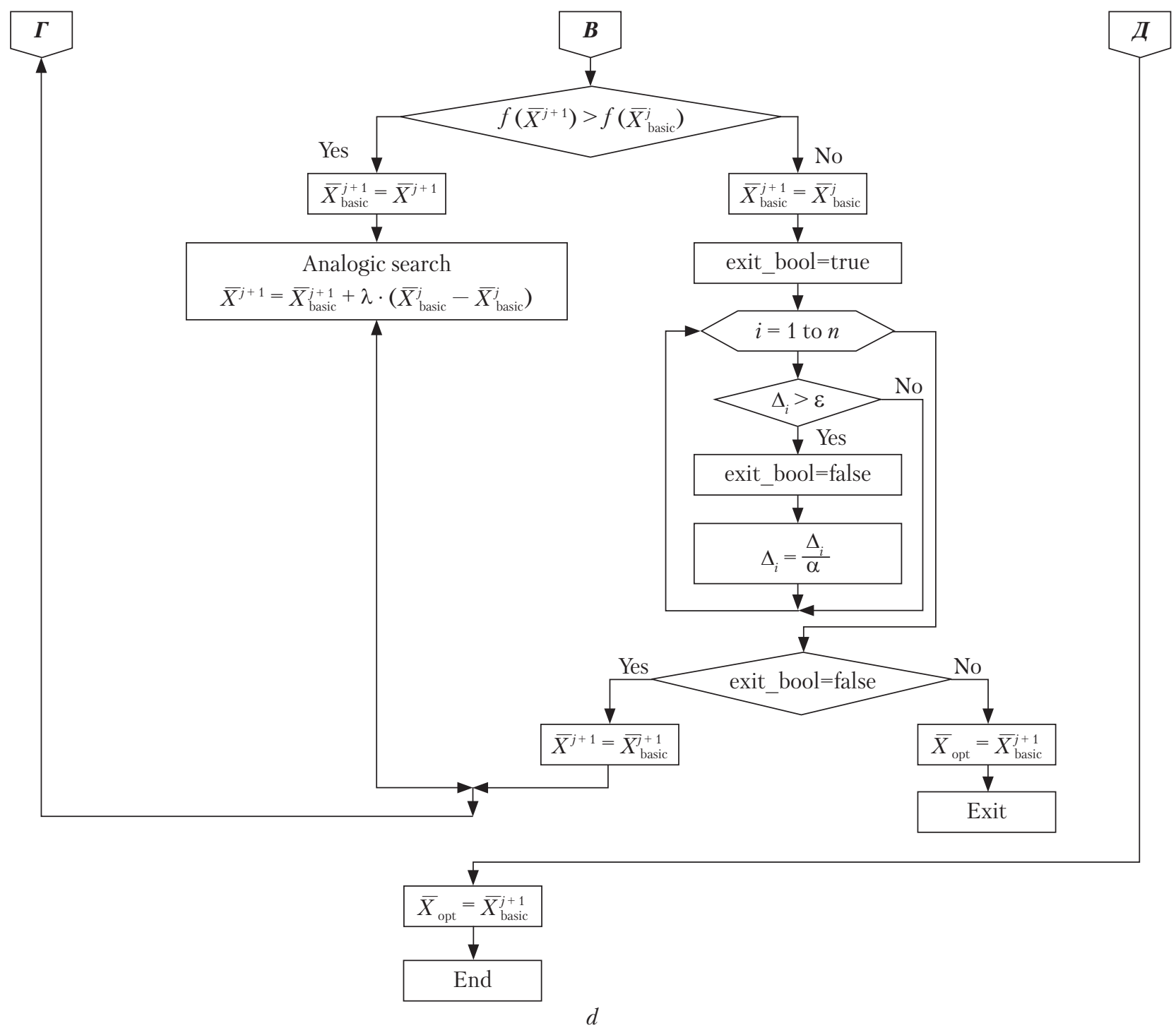

Fig. 2. End

illustrative example while optimizing the design parameters, the trajectory parameters, and the main characteristics of the GM.

For the practical application of the proposed approach with the use of zero-order configurations method (the Hook-Jeeves), the vector $\bar{p}$ whose components, as mentioned above, include basic GM design parameters and the trajectory parameters has been optimized. A one-stage controlled object with a launch mass $m_{0}=800 \mathrm{~kg}$ and a mass of the reentry vehicle $m_{\Gamma \Psi}=220 \mathrm{~kg}$ is con- sidered as a guided missile. The parameters to be optimized (vector $\bar{p}$ ) are selected based on the condition for the maximum of objective function of the range $L=L(\bar{p}, \bar{x})$ to which the required mass of reentry vehicle shall be delivered.

A solid rocket propellant engine with a conditional propellant is used as a GM power plant. The calculations used the exponential dependence of the SRP combustion rate on the pressure, which is determined by relationship [20,21]:

$$
u=u_{1} \cdot\left(p_{\mathrm{k}}\right)^{v} \text {, }
$$


Table 1. Initial Data that Remain Unchanged While Optimizing

\begin{tabular}{|l|c|l|}
\hline Parameter & Value & \multicolumn{1}{|c|}{ Description } \\
\hline$m_{0}, \mathrm{~kg}$ & 800.0 & Launch mass of the GM \\
$m_{\text {Гч}}, \mathrm{kg}$ & 220.0 & Mass of the reentry vehicle \\
$D_{\text {уРО }}, \mathrm{m}$ & 0.35 & Diameter of cylindrical part of the GM \\
$L_{\text {Гч }}, \mathrm{m}$ & 1.7 & Total length of the reentry vehicle \\
\hline
\end{tabular}

Table 2. Range of Variations of Parameters to be Optimized

\begin{tabular}{|c|c|c|c|}
\hline \multirow{2}{*}{ Parameter } & \multicolumn{2}{|c|}{ Value } & \multirow{2}{*}{ Note } \\
\hline & $\min$ & $\max$ & \\
\hline$v_{p},[-]$ & 0.07 & 0.11 & Initial thrust coefficient \\
\hline$\mu k,[-]$ & 0.3 & 0.5 & Relative remaining mass \\
\hline$p k, \mathrm{~kg} \mathrm{~s} / \mathrm{cm}^{2}$ & 65.0 & 95.0 & $\begin{array}{l}\text { Pressure in the combustion } \\
\text { chamber of SRP engine }\end{array}$ \\
\hline$D_{a}, \mathrm{~m}$ & 0.30 & 0.34 & $\begin{array}{l}\text { Diameter of nozzle section of } \\
\text { SRP engine }\end{array}$ \\
\hline$t_{\text {vert }}, \mathrm{s}$ & 2.0 & 5.0 & Duration of the vertical flight \\
\hline$\varphi_{c m}$, deg. & 60.0 & 80.0 & $\begin{array}{l}\text { GM tilt angle in the case of } \\
\text { oblique start }\end{array}$ \\
\hline$\varphi_{\text {AUT }}$, deg. & 35.0 & 60.0 & $\begin{array}{l}\text { Pitch angle at the end of the } \\
\text { active leg }\end{array}$ \\
\hline$t_{P U T 1}, \mathrm{~s}$ & 2.0 & 90.0 & $\begin{array}{l}\text { Duration of entering the at- } \\
\text { tack angle } \alpha=0,0^{\circ}\end{array}$ \\
\hline$\alpha_{\text {const }}$, deg. & 5.0 & 15.0 & Attack angle in an inactive leg \\
\hline$t_{\text {PUT3 }}, \mathrm{s}$ & 3.0 & 10.0 & $\begin{array}{l}\text { Duration of entering the at- } \\
\text { tack angle } \alpha=\alpha_{\text {const }}\end{array}$ \\
\hline
\end{tabular}

where $p_{\mathrm{k}}$ is pressure in the combustion chamber of SRP sustainer $\left[\mathrm{kg} \mathrm{s} / \mathrm{cm}^{2}\right] ; u_{1}[\mathrm{~m} / \mathrm{s}], v$ are the parameters that define dependence of SRP combustion rate on pressure in the combustion chamber.

The aerodynamic scheme of the GM is formed from the reentry vehicle that is a combination of ogive (a streamlined 3D shape, intermediate between the cone and the ellipsoid) and cylindrical parts. The cylindrical part contains the transfer and tail compartments and the body of the combustion chamber of SRP sustainer. In the tail compartment, there are aerodynamic rudders to control the missile object in flight. The total length of GM is $L_{\ulcorner\Psi}=1.7 \mathrm{~m}$, the length of ogive part of the reentry vehicle is $L_{\text {ож }}=0.5 \mathrm{~m}$, the length of the cylindrical part of the reentry vehicle is $L_{\mathrm{II}}=1.2 \mathrm{~m}$.

\section{Table 3. GM Optimal Design Parameters}

\begin{tabular}{|l|l|l|}
\hline \multicolumn{1}{|c|}{ Parameter } & \multicolumn{1}{|c|}{ Value } & \multicolumn{1}{c|}{ Description } \\
\hline $\begin{array}{l}v_{p},[-] \\
\mu k,[-]\end{array}$ & 0.11 & $\begin{array}{l}\text { Initial thrust coefficient } \\
\text { Relative remaining mass of the GM } \\
p k, \mathrm{~kg} \mathrm{~s} / \mathrm{cm}^{2}\end{array}$ \\
$\begin{array}{l}70.486582 \\
D_{a}, \mathrm{~m}\end{array}$ & 0.3025 & $\begin{array}{l}\text { Pressure in the combustion cham- } \\
\text { ber of the sustainer } \\
\text { Diameter of the nozzle section of } \\
\text { the sustainer }\end{array}$ \\
\hline
\end{tabular}

Table 4. Optimal Parameters

for the Two Options of GM Trajectory

\begin{tabular}{|l|c|c|c|c|}
\hline \multirow{2}{*}{$\begin{array}{l}\text { Trajectory } \\
\text { parameter }\end{array}$} & \multicolumn{4}{|c|}{ Value } \\
\cline { 2 - 5 } & \multicolumn{2}{|c|}{$\alpha_{H \max }=0.0^{\circ}$} & $\alpha_{H \max }=\alpha_{\text {const }}=14.53^{\circ}$ \\
\cline { 2 - 5 } & \multicolumn{2}{|c|}{ Type of launch } & \multicolumn{2}{|c|}{ Type of launch } \\
\cline { 2 - 5 } & Vertical & Oblique & Vertical & Oblique \\
\hline$L, \mathrm{~km}$ & 144.349 & 151.521 & 201.859 & 210.192 \\
$t_{\text {vert }}, \mathrm{s}$ & 2.0 & 0.0 & 2.0 & 0.0 \\
$\varphi_{\text {cm }}, \mathrm{deg}$. & 90.0 & 74.38 & 900 & 73.75 \\
$\varphi_{\text {AUT }}, \mathrm{deg}$. & 52.97 & 52.58 & 51.02 & 51.02 \\
$t_{\text {PUT1 }}, \mathrm{s}$ & 70.28 & 72.06 & 68.5 & 78.0 \\
$H_{\text {max }}, \mathrm{km}$ & 55.253 & 55.087 & 51.825 & 52.002 \\
$t_{\text {PUT3 }}, \mathrm{s}$ & 0.0 & 0.0 & 3.0 & 3.0 \\
\hline
\end{tabular}

Table 5. The Basic Characteristics of the GM

\begin{tabular}{|c|c|c|}
\hline Parameter & Value & Note \\
\hline$P_{\text {pust }}, \mathrm{kg} \mathrm{s}$ & 7272.7 & $\begin{array}{l}\text { Thrust in space in the main operation } \\
\text { mode }\end{array}$ \\
\hline$m_{c}, \mathrm{~kg} / \mathrm{s}$ & 26.067 & $\begin{array}{l}\text { Mass consumption of combustion } \\
\text { products per } 1 \mathrm{~s}\end{array}$ \\
\hline$t \sum, \mathrm{s}$ & 16.52 & Full time of the sustainer operation \\
\hline$d_{k r}, \mathrm{~m}$ & 0.091 & $\begin{array}{l}\text { Diameter of the critical section of the } \\
\text { sustainer nozzle }\end{array}$ \\
\hline$m \sum_{m}, \mathrm{~kg}$ & 410.73 & Total propellant load of the sustainer \\
\hline$m_{\mathrm{RDTT}}^{\Sigma}, \mathrm{kg}$ & 489.54 & Total mass of the sustainer \\
\hline$L_{\mathrm{RDTT}}^{\sum}, \mathrm{m}$ & 3.546 & Total length of the sustainer \\
\hline$L_{\mathrm{yPO}}, \mathrm{m}$ & 5.334 & Total length of the GM \\
\hline
\end{tabular}

The combustion chamber, the transfer and tail compartments are made of steel. The diameter of the cylindrical part is $D_{\mathrm{yPO}}=0.35 \mathrm{~m}$.

The basic parameters to be optimized are: coefficient of initial thrust of the GM in space $v_{p}$, average pressure in the combustion chamber in the 
main operation mode $p_{k}$, and diameter of nozzle section of SRP engine $D_{a}$.

The total propellant load of SRP sustainer $m_{m}^{\Sigma}$ and design parameter of the GM $\mu_{k}$ are calculated based on given launch mass of the GM $m_{0}^{m p}$ and mass of the reentry vehicle $m_{\mathrm{\Gamma \Psi}}^{m p}$ depending on basic design parameters $v_{p}, p_{k}$ and $D_{a}$, and properties of conventional solid rocket propellant.

The following parameters are considered the GM trajectory parameters: in the case of vertical launch, duration of the vertical portion $t_{\text {vert }}$; in the case of oblique launch, tilt angle, while launching $\varphi_{c m}$. In addition to these parameters that depend on the type of launch, the following parameters are optimized: pitch angle at the end of the active $\operatorname{leg} \varphi_{A U T}$, duration of entering the zero attack angle after the active leg of the trajectory $t_{P U T 1}$, constant attack angle $\alpha_{\text {const }}$ in an inactive leg for the use of an option of ballistic trajectory, and duration of entering the attack angle $\alpha=\alpha_{\text {const }}$ after reaching the maximum altitude $t_{P U T 3}$.

The parameter vector $\bar{p}$ is optimized for the two options of the trajectory:

- flight with the zero attack angle after reaching the maximum altitude;

- flight with a nonzero attack angle $\alpha=\alpha_{\text {const }}$ after reaching the maximum altitude.

Calculations were performed for both inclined and vertical types of KO launch.

The initial data that remain unchanged in the process of optimization of design parameters and trajectory parameters are given in Table 1, and the ranges of variations of the optimized parameters are shown in Table 2.

As a result of the optimization, the optimal values of the main design parameters characterizing the GM have been found to be the same for the two types of ballistic trajectory considered. Type of launch (vertical and oblique) also does not affect the optimal values of the main design parameters. The type of ballistic trajectory and the type of launch influence only the parameters of the optimized trajectory. The results of optimization of the main design parameters are shown in Table 3.

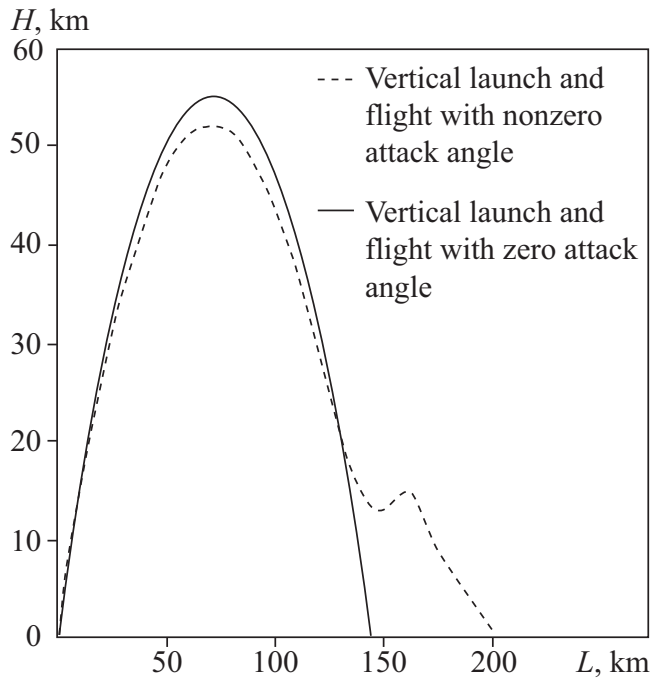

Fig. 3. Trajectory with $\alpha_{H \max }=0.0^{\circ}$ and $\alpha_{H \max }=14.53^{\circ}$ after reaching the maximum altitude, in the case of vertical launch

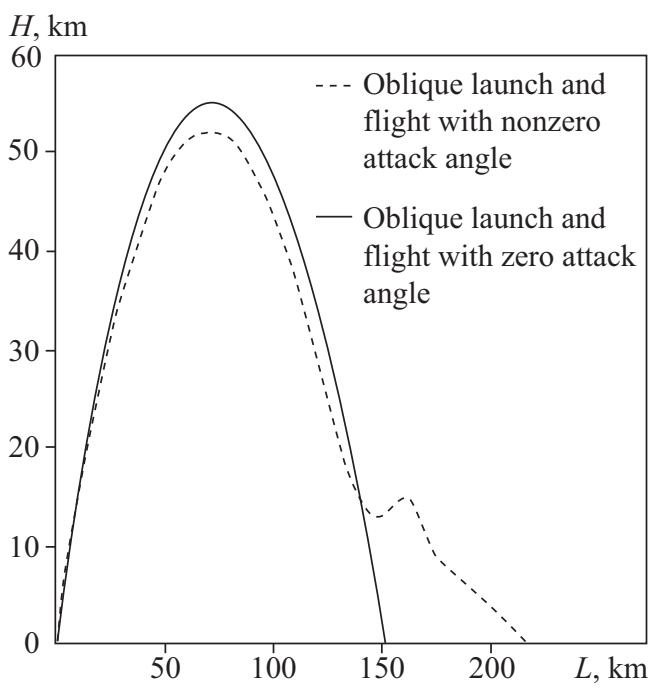

Fig. 4. Trajectory with $\alpha_{H \max }=0.0^{\circ}$ and $\alpha_{H \max }=14.53^{\circ}$ after reaching the maximum altitude, in the case of oblique launch

The results of parameter optimization for different types of ballistic trajectories with zero attack angle $\alpha_{H \max }=0.0^{\circ}$ and attack angle $\alpha_{H \max }=$ $\alpha_{\text {const }}$ after reaching the maximum altitude are given in Table 4.

The basic characteristics of the GM obtained from the optimization are given in Table 5.

Fig. 3 shows the dependence of altitude $H$ on the flight range $L$ in the case of vertical launch, 
for the two options of ballistic trajectory with $\alpha_{H \max }=0.0^{\circ}$ after reaching the maximum altitude and with $\alpha_{H \max }=14.53^{\circ}$ after reaching the maximum altitude.

Fig. 4 features the dependence of altitude $H$ on the flight range $L$ in the case of oblique launch, for the two options of ballistic trajectory with $\alpha_{H \max }=0.0^{\circ}$ after reaching the maximum altitude and with $\alpha_{\mathrm{Hmax}}=14.53^{\circ}$ after reaching the maximum altitude.

As the research has shown, the option of ballistic trajectory and type of launch influence the objective function, the flight range $L$. In the case of vertical launch, the flight range for the trajectory with $\alpha_{H \max }=0.0^{\circ}$ after reaching the maximum altitude is $\sim 57.5 \mathrm{~km} \mathrm{~km}$ less than that in the case of $\alpha_{H \max }=14.53^{\circ}$. In the case of oblique launch, an increase in the flight range is about $58.7 \mathrm{~km}$.

As compared with the vertical launch, the oblique launch gives an increase in the flight range of $\sim 7.2 \mathrm{~km}$ for the trajectory with $\alpha_{H \max }=0.0^{\circ}$ after reaching the maximum altitude and about $8.3 \mathrm{~km}$ in the case of $\alpha_{H \max }=14.53^{\circ}$.

Since variations of these optimized parameters in the considered ranges of their values significantly affect the objective function, the optimization of these parameters for specific mission profiles is a necessary step in the design process.
The proposed complex problem and the method for optimization of GM parameters, trajectory parameters, and motion control programs can be used without significant improvements in the design of GM of different classes.

Thus, the complex problem of optimizing the design parameters, the motion control programs, and the basic characteristics of GM has been formulated; the structure of the GM mathematical model and the algorithm for calculating the objective function to determine dimensional, energy, aerodynamic, and ballistic characteristics of the controlled object at the initial stage of design have been presented. Using computer technology, applications have been developed to present research results in a user-friendly graphical form. The developed methodical framework has been tested by example of the solution of design problem of GM motion for two options of ballistic trajectories. The expediency of the method of zero-order configurations (the Hooke-Jeeves method), which does not require the calculation of partial derivatives of the objective function of flight range by optimized parameters, which makes it possible to significantly reduce the time to find the optimal solution for the complex problem of optimizing the design parameters, the motion control programs, and the basic characteristics of GM.

\section{REFERENCES}

1. Degtyarev, A. V. (2014). The problems and prospects of missilery. Dnepropetrovsk: ART-PRESS [in Ukrainian].

2. Mishin, V. P., Bezverbyi, V. K., Pankratov, B. M., Sheverov, D. N. (1985). Basic designing of aerial vehicles. The manual for technical universities. Moscow: Mashinostroenie [in Russian].

3. Shcheverov, D. N. (1978). Designing of unmanned aerial vehicles. Moscow: Mashinostroenie [in Russian].

4. Sinyukov, A. M., Volkov, L. I., L'vov, A. I., Shishkevich, A. M. (1972). The ballistic solid propellant rocket. Moscow: Voenizdat [in Russian].

5. Varfolomeev, V. I., Kopytov, M. I. (1970). Designing and testing of ballistic missiles. Moscow: Voenizdat [in Russian].

6. Vinogradov, V. A., Grushchanskii, V. A., Dovgodush, S. I., Ilichev, A. V. (1989). The efficiency of complex systems. Dynamic models. Moscow: Nauka [in Russian].

7. Ilichev, A. V., Volkov, V. D., Grushchanskii, V. A. (1982). The efficiency of the designed elements of complex systems. Moscow: Vysshaya shkola [in Russian].

8. Krotov, V. F., Gurman, V. I. (1973). The methods and problems of optimal control. Moscow: Nauka [in Russian].

9. Pontryagin, L. S., Boltyanskii, V. G., Gamkrelidze, R. V., Mishchenko, E. F. (1969). The mathematical theory of optimal processes. Moscow: Nauka [in Russian].

10. Tarasov, E. V. (1970). The algorithm of optimal engineering of the rocket. Moscow: Mashinostroenie [in Russian].

11. Alpatov, A. P., Senkin, V. S. (2011). The complex problem of the simultaneous optimization of the basic design parameters and motion control programs of guided missiles. Technical Mechanics, 4, 98-113 [in Ukrainian]. 
12. Alpatov, A. P., Senkin, V. S. (2013). The methodology for the choice of design and the optimization of the design parameters and control programs of the launch vehicle. Technical Mechanics, 4, 146-161 [in Ukrainian].

13. Senkin, V. S. (2009). The optimization of project parameters of the ultra-light class launch vehicle. Technical Mechanics, 1, 80-88 [in Ukrainian].

14. Aksenenko, A. V., Baranov, E. Yu., Gurskii, A. I., Klochkov, A. S., Morozov, A. S., Alpatov, A. P., Senkin, V. S., SyutkinaDoronina, S. V. (2018). The methodology for the early design phase to optimize design parameters, trajectory parameters and motion control programs for guided missile. Space Technology. Missile Armaments, 2(116), 101-116 [in Ukrainian].

15. Syutkina-Doronina, S. V. (2017). The problem of the optimization the design parameters and control programs of the guided missile with main solid rocket motors. Aerospace technic and technology, 2(137), 44-59 [in Ukrainian].

16. Senkin, V. S. (2012). The complex problem to optimize design parameters and control programs of the super light solid launch vehicle. Technical Mechanics, 2, 106-121 [in Ukrainian].

17. Senkin, V. S. (2018). The problem of the choice of the motion control programs for guided missile capable of flying along the ballistic trajectory. Technical Mechanics, 1, 48-59 [in Ukrainian].

18. Lebedev, A. A., Gerasyuta, N. F. (1970). The ballistics of the rockets. Moscow: Mashinostroenie [in Russian].

19. Razumev, V. F., Kovalev, B. K. (1976). Fundamentals of design of the ballistic solid-propellant rockets. Moscow: Mashinostroenie [in Russian].

20. Erokhin, B. T. (1982). The theoretical Design Basics of solid rocket motors. Moscow: Mashinostroenie [in Russian].

21. Abugov, D. I., Bobylev, V. M. (1987). The theory and calculation of the solid rocket motors. Moscow: Mashinostroenie [in Russian].

22. Shishkov, A. A. (1974). The gas dynamics of gunpowder rocket motors. Moscow: Mashinostroenie [in Russian].

23. Panteleev, A. V., Letova, T. A. (2005). The optimization methods in examples and tasks. Moscow: Vysshaya shkola [in Russian].

24. Senkin, V. S., Syutkina-Doronina, S. V. (2018). The joint use of the random search methods with gradient ones of the optimization of design parameters and control programs of the guided missile. Technical Mechanics, 2, 44-59 [in Ukrainian].

25. Senkin, V. S., Syutkina-Doronina, S. V. (2019). The problem of the choice of optimization methods of design parameters and control programs of the guided missile. Technical Mechanics, 1, 3-17 [in Ukrainian].

Received 17.07.19

Revised 21.10.19

Accepted 28.10.19

\section{В.С. Сєнькін, С.В. Сюткіна-Дороніна}

Інститут технічної механіки Національної академії наук України

і Державного космічного агентства України,

вул. Лешко-Попеля, 15, Дніпро, 49005, Україна,

+380563720640,+380563720640, office.itm@nas.gov.ua

\section{ДО ПИТАННЯ ВИБОРУ МЕТОДУ ОПТИМІЗАЦІЇ ПАРАМЕТРІВ КЕРОВАНОГО ОБ'ЄКТА}

Вступ. Проєктування керованих об'єктів (КО) пов’язано зі значними витратами матеріальних і фінансових ресурсів. Потреба їх зниження на початковому етапі проєктування КО висуває підвищені вимоги до формалізації проєктних задач, методів їх вирішення, адекватності використовуваних математичних моделей, якості прийнятих проєктних рішень.

Проблематика. Однією з проблем, що пов’язана з проєктуванням КО, є створення методичного забезпечення для оптимізації проєктних параметрів і програм керування рухом ракетних об’єктів.

Мета. Розробка методичного забезпечення для вибору проєктних параметрів і програм керування, а також формалізація задачі і вибір методу оптимізації характеристик КО, що здійснює політ за різними траєкторіями.

Матеріали й методи. Для вирішення задачі нелінійного математичного програмування з обмеженнями у вигляді рівностей і диференціальних зв’язків використано детерміновані методи оптимізації.

Результати. Розроблено прикладні програми для вирішення задачі оптимізації щодо одноступінчатого КО 3 ракетним двигуном на твердому паливі. Проведено апробацію методичного забезпечення на прикладі розв'язання 
проєктної задачі щодо гіпотетичного КО зі стартовою масою 800 кг, який здійснює політ балістичною траєкторією, для вертикального і похилого видів старту. Показано доцільність застосування при вирішенні задачі методу конфігурацій нульового порядку (методу Гука-Дживса), який не потребує розрахунку часткових похідних цільової функції за оптимізованими параметрами, що дозволяє істотно скоротити час пошуку оптимального рішення комплексної задачі.

Висновки. Використання розробленого авторами методичного забезпечення дозволяє 3 необхідною для проєктних досліджень точністю визначати оптимальні в заданому класі функцій програми керування рухом, раціональні значення проєктних параметрів та основних характеристик КО.

Ключові слова: керований об’єкт, математична модель, проєктні параметри, параметри траєкторії, програма керування рухом, оптимізація, початковий етап проєктування, ракетний двигун на твердому паливі. 